\title{
The company and its responsibility in the national and international context
}

\section{La empresa y su responsabilidad en el contexto nacional e internacional}

\author{
SANROMÁN-ARANDA, Roberto $\dagger^{*}$ \\ Universidad Autónoma del Estado de México, Centro Universitario UAEM Valle de México.
}

ID $1^{\text {st }}$ Author: Roberto, Sanromán-Aranda / ORC ID: 0000-0002-0682-6343

DOI: $10.35429 / J B S .2020 .17 .6 .18 .26$

Received February 10, 2020; Accepted April 01, 2020

\begin{abstract}
The company as an economic activity is immersed from the economic, legal, administrative and even often social point of view. When having the need to offer quality goods and services is forced to have different controls and different mechanisms that make it a socially responsible company and that have an impact in the international context, especially in the exchange of goods and services. they offer by technological and electronic means what reverberates throughout the world in a massive and vertiginous way. The company is responsible for the damage caused by its activity, often without the intention of causing such damage, simply by the dynamism it performs, which may have repercussions within the national territory or outside, depending on the execution of its business activity.
\end{abstract}

Social responsibility, Company, National and international context, Damage

\begin{abstract}
Resumen
La empresa como actividad económica se ve inmersa desde el punto de vista económico, jurídico, administrativo e incluso muchas veces en lo social. Al tener la necesidad de ofrecer bienes y servicios de calidad se ve obligada a contar con distintos controles y mecanismos que la hacen ser una empresa socialmente responsable y que repercuten en el contexto internacional, sobre todo en el intercambio de los bienes y servicios que se ofrecen por medios tecnológicos y electrónicos lo que repercute en todo el mundo de un modo masivo y vertiginoso. La empresa se hace responsable de los daños que cause por su actividad, muchas veces sin intención de causar dicho daño, sencillamente por el dinamismo que desempeña, que puede tener repercusiones dentro del territorio nacional o fuera, dependiendo de la ejecución de su actividad empresarial.
\end{abstract}

Responsabilidad social, Empresa, Contexto nacional e internacional, Daño

Citation: SANROMÁN-ARANDA, Roberto. The company and its responsibility in the national and international context. Journal of Business and SMEs. 2020. 6-17: 18-26.

*Correspondence to the Author (Email: r_sanroman31@ @otmail.com)

$\dagger$ Researcher contributing first author. 


\section{Introduction}

In this research we will talk about the company and its social responsibility that it has had in relation to the community to which it is owed, in the satisfaction of the goods and services that must be of quality and also how they often cause damage and damages for their lack of control in the care of the production or in the provision of the service and that said damages can be caused both nationally and internationally.

It will be mentioned about how important it is to be aware of both public and private institutions, in the prevention of damages that may be caused by bad products or services offered through different means such as the case of technological.

It will talk about the strategic decisions that the employer must consider and that affect the groups or people of interest that can be found in their environment.

The question should be asked: Will the compensation established by law and established by the judges for damages from the company, both nationally and internationally, be sufficient? How far does corporate social responsibility go in the international context? These questions and others that we can ask will be given possible answers, this does not mean that there are not a greater number of questions and solutions in this regard that can be addressed by other investigations.

\section{The company and its business development}

The company was born as a social need addressed to the group of consumers with the production and distribution of goods and services, historically it is stated that: "Companies emerged as a consequence of the Industrial Revolution, which not only changed the structure of production, but also of the social organization and distribution of work; in such a way that the master craftsman was replaced by the businessman; the small workshop by the factory or company, later; and the artisans for the employees."

\footnotetext{
6 Mendizábal Bermúdez. Gabriela "Analysis of Corporate Responsibility in Mexico in front of workers." Institute of Legal Research UNAM. Mexico. P. 126. In. https://revistas.juridicas.unam.mx/index.php/derecho-

social/article/download Consulted on February 15, 2019.
}

This event, which was generated at an important stage in history, had an international impact that has reverberated in all countries, both socially, legally, culturally and economically. The industrial revolution marked companies from different points of view, including also in the workplace, regulating accidents of workers, working hours, among other aspects and environmental, since with the appearance of machining, damage and regulation are also caused of ecosystems, that is, of nature and its environment.

The company as an activity, be it of a legal, economic or administrative nature, has very important subjective elements, the businessman and the worker or employee, which are necessary for its development, companies are fundamental in the development of a country, in some way, to the extent that they are productive, both goods and the provision of services will serve to measure the well-being of a nation; Business progress affects the national and international context in general, this is also due to the effect brought by the globalization of countries, with the exchange of goods and services that are in a massive way and, as we know in the international arena, can be give positive as well as negative questions. Vgr.

In the massive importation of products that displace the national industry, this situation has a negative effect on the country in its production of said goods, bringing serious damage to the Mexican company that is mainly affected by said event of an economic nature.

It must be borne in mind that "The preservation of a certain harmony between the different economic entities that participate in the market translates into great benefits for those who consume, since they can choose between different kinds of fruits and enjoy better prices and new products. On the other hand, companies, in a free and clean market, will find an engine that encourages them to increase their efficiency and improve their quality. (...) 
Those who provide services and offer goods must be careful that their commercialization and production are carried out in optimal conditions, so that they do not harm the health or safety of consumers and users, in which case the companies that caused the damage" ${ }^{37}$.The free participation of economic entities in the production of goods and services is essential in a market so that it is prosperous and for the benefit of the community and society to which said production is directed, which must be offered quality, informed on the composition of the content of products and in accordance with the needs of consumers.

On the other hand, nowadays the term responsibility has been widely used, in previous decades it began to be used in relation to the environment, however with the passage of time companies took it, to apply it to their daily actions, as a productive company, it is important, since to the extent that a company is responsible for the development of its activities, it contributes to social welfare by giving collective benefits, such as good corporate practices, compliance with its quality standards in the products or services it offers, preserving the environment as a right and a good, among many aspects that also impact the exterior of a nation, as another of them could be the environment and its ecosystems.

It is important to know the origin of the word responsibility, since to that extent we will know how to limit ourselves to the term, reason why "Etymologically the term responsibility comes from the word" respond ", which is derived from the Latin I will respond, defined as" promise to your future, promise or pay in turn, correspond to, keep the debt in proportion to one thing with another, be in agreement, agree, answer the accusations, reject them, debate them "(...) also refers to guarantor, to assume something, to commit to something before someone. " 8

\footnotetext{
${ }^{7}$ Pabón Mantilla Ana Patricia, Javier Orlando Aguirre Román and Mónica Cristina Puentes Celis. "Corporate Social Responsibility: The Perspective of Constitutional Jurisprudence" Juridical Criterion Santiago de Cali V. 9, No. 2 pp. 163 and 164 Consulted on October 21, 2019 at: https://core.ac.uk/download/pdf/ 52201928.pdf

8 Elva Esther Vargas Martínez. (2015) "Corporate social responsibility and environmental management in the hotel sector." Edited by UAEM. Mexico 2015. Page 47.
}

The responsibility, despite being a term widely used since ancient times, has had great use in modern times, in search of the existence of social harmony, of making us aware of our activities that we carry out on a day-to-day basis that impact on the both national and international context, in the constant human and logically business relationships that is the central theme of the present investigation. There is also talk of "social responsibility, the analysis must start from understanding it as an ethical-moral commitment of individuals, groups, entities, organisms and institutions with society." 9

The company in its beginnings is developed with the family, known as a family business, as it grows, strangers or third partners enter the same family with whom they progress in a national and international context, so due to their expansion they become in true impersonal companies and that many are currently listed on the stock exchange, which have a social and corporate impact throughout the world.

Undoubtedly, companies seek to penetrate international markets, often merging with others and creating gigantic corporations, so that as their responsibilities increase, efforts are made to satisfy the needs of the community, which must be socially responsible and the socalled ethical company, understanding it as: “A) Co-responsibility within the company does not mean that all the people who work in it are at the same level; it simply means that each one is in charge of the work that corresponds to him according to his capacities and is completely responsible for that part. (...) B) The company is no longer exclusively a machine to produce merely economic benefits, since it is conceived more as an organization endowed with culture. (...) C) The corporate culture is inclusive of its components. Now, this does not mean that there must be an instrumentalization of values to achieve a better exploitation of human resources. (...) D) The social balance represents "the effort to describe in internal or external reports as much data as possible about the benefits and costs that the business activity brings - or can bring - to society in a given period of time" $(\ldots)$.

\footnotetext{
9 Torres, J. B., \& Alemán, L. S. (2020). The social responsibility of the state company in the full exercise of the rights of workers in the state company in Cuba IUS MAGAZINE, 14 (45) Page 57.
}

SANROMÁN-ARANDA, Roberto. The company and its responsibility in the national and international context. Journal of Business and SMEs. 2020 
E) We can speak not only of an ethic of disinterest, but also of the common interest; not only of conviction, but also of responsibility; not only of a personal ethic, but also of social activities, institutions and organizations". ${ }^{10}$ As can be seen, the company is not only an isolated economic entity that seeks profit but has an influence on the development of society. We must remember that the progress and wealth of a country is measured by the production of goods and services, but these are influenced by the different factors in the company, which we mentioned in the preceding paragraph.

As is known, the word responsibility implies being responsible for our actions, to the extent that we cause any damage or have a certain commitment to third parties, whether physical or moral. In addition, we must also respond to situations that are beyond our reach, which is known as strict liability, which is regulated in the Federal Civil Code and which provides in its article 1913: "When a person uses mechanisms, instruments, devices or dangerous substances by themselves, by the speed they develop, by their explosive or flammable nature, by the energy of the electric current they conduct or by other analogous causes, is obliged to answer for the damage it causes, although not act unlawfully, unless it demonstrates that the damage was caused by the fault or inexcusable negligence of the victim. " From the above, it follows that both a natural and a moral person must answer for the handling of their devices, substances, equipment, machinery, etc., regardless of the fact that there is no intention to cause any damage, so as you can see, the responsibility has vast effects and important in the world of the human being and especially in the subject of the company that is the aspect that corresponds to us due to the importance that it has in the social environment.

The aforementioned reflects how important and broad is the responsibility that a person may incur. For the assumption that concerns us about social responsibility, the situation can arise in which the company, in order to achieve its activities, must be aware of complying with the damages that it may cause and as has already been said, even without being at fault .
As well as this assumption, there are many more, such as the responsibility to have quality control in companies, to respond to the pollution they cause to the environment, to take care that their waste does not cause damage to the environment, to offer services with care , ethical and quality values, among other responsibilities.

In principle, the responsibility of the company is regulated in the different laws, regulations, agreements, however there are others contained in the different international treaties such as the commercial ones to which Mexico is a party. There is also responsibility on the part of companies in the international arena, regardless of whether they have signed said treaty; It could be the case that your products are marketed in other countries and cause some damage, or that your waste contaminates other places, although these situations will not be provided for in a certain international treaty, in any case you must respond according to the international reciprocity that exist with the different nations in the world and the responsibility that exists for having caused damage and going against international principles or international rules that can significantly affect countries that live in a globalized world in the international context, since there must be a harmony between the States and an international peace that strengthens them in acting in the context in which they move in their multiple relationships and commercial exchanges.

The company must seek the well-being of its members, be they partners or employees, as well as the community, which is the focus of its efforts to deliver quality products or services at affordable prices to the population to whom they are intended. "According to the World Bank, when speaking of Corporate (or corporate) Social Responsibility in its simplest form, reference is made to the activity of" doing business based on ethical principles and in accordance with the law ", since the company (not the entrepreneur) has a role before society and before the environment in which it operates, which has a positive or negative impact, depending on its performance. 
In this sense, the international entity clarifies that being socially responsible does not imply acts of philanthropy or charity, but rather has to do with the position that organizations must adopt vis-à-vis the actions of their productive activity and the impact they produce. ; a position that must be active and with a high degree of responsibility"11 Of the above, it should also be mentioned that the company's activity affects the economic progress of a country, in accordance with the principles of good commercial and corporate practices that must prevail harmoniously in the business world in different relationships, both national and international, so in the global context there must prevail a harmony between companies, operate with solid foundations and institutional values in pursuit of global wellbeing and logically an economic and social benefit, which will contribute to the economic growth of the countries and quality of life for the people who make them up.

The company must seek a benefit for its workers or employees, comply with the development of quality products, seek its environment will be favored with its activities, both for consumers and those who are not the child, such as interest groups stories such as settler associations, NGOs (Non-Governmental Organizations), business organizations, residents of the area in which they settle, unions, among others; In some way, a social benefit must be sought above the private good of the company.

It must be considered that within the business environment, the decisions made by companies may affect third parties, there are individuals or organizations, whether they are customers, employees, the community in general, among others, that can impact them, economically, socially, labor or environmental, so it must always be borne in mind that no harm is caused to said groups or persons of interest who are in the environment of the company, in which they carry out activities to achieve their fines, companies or corporations .
Therefore, when making strategic or vital decisions for the company and society, the entrepreneur must consider these groups or people and must not only seek economic gain, but a good for consumers and the community, which is their reason for exist and this constitutes a social responsibility that has the duty to fulfill and that owes it to the society in which it develops, in the corporate world.

\section{Considerations of the damages that companies can cause at the national and international level}

The company, by carrying out its activities, is no stranger to causing damages to the community that have an important impact on the world of consumers, even more so the effect of globalization gives greater magnitude to said problem, since while its sphere of action is broader, the consequences will be greater, since the impact will not only be for the country internally but with other nations with which different businesses or commercial activities were carried out. When using the term globalize, it involves many aspects, such as cultural, technological, economic, to name a few. To the extent that companies comply with their obligations, in the delivery of quality products, complying with the agreed conditions, in terms of time and form, they will not generate harm, that is: "Contracting an obligation and fulfilling it does not imply that you are giving a responsibility, since this occurs as a consequence of not complying with any obligation, so that damage is caused, and therefore the person responsible will have to pay the damages caused to the victim who suffers them." 12 There are different ways of marketing or distributing goods and services, so it is important to mention that currently they are offered through technology, which brings a massive exchange, not only internally in the country, but in international exchange, so mechanisms must be sought to control commercial malpractices, which are regulated in the various international treaties, - such as the recently updated and signed free trade agreement between Mexico, Canada and the United States, in which the exchanges of goods and services between the three countries are regulated.

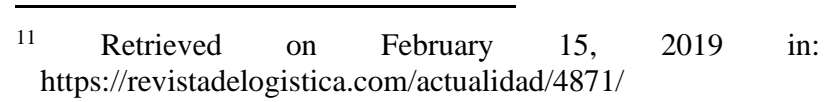


However, there must also be preventive measures, such as legends contained in technological means, as there are already reflected in some products that clarify the harmful effects they may cause, eg. the case of the consumption of cigarettes, alcohol, in which the legend appears, that the consumption of such products may be harmful to health, among other goods, in addition to this, the final recipients must be alerted to defects that may contain the products or services offered by companies, whether national or transnational. Even in the Federal Consumer Prosecutor's Office there is a magazine that publishes the prices, qualities, among other aspects offered by the various companies, so that the consumer knows them and acquires them with the best conditions of the products offered, they contain them.

Even in the Federal Law on Consumer Protection, the payment of damages when caused to the consumer is established: in accordance with the following articles of the Law in question: "Art 41 says: When it comes to products or services that In accordance with the applicable provisions, they are considered potentially dangerous for the consumer or harmful to the environment or when their dangerousness is foreseeable, the supplier must include instructions that warn about their harmful characteristics and clearly explain the recommended use or destination and the possible effects of its use, application or destination outside the recommended guidelines. The provider shall be liable for the damages caused to the consumer by the violation of this provision, without prejudice to the provisions of article 92 TER of this law.

Article 92.- Consumers will have the right, at their choice, to the replacement of the product or to the refund of the amount paid, against the delivery of the purchased product, and in any case, to a bonus, in the following cases:

I. When the net content of a product or the quantity delivered is less than that indicated on the container, container, or when measuring instruments that do not comply with the applicable provisions are used, considering the tolerance limits allowed by the regulations;
II. If the good does not correspond to the quality, brand, or specifications and other substantial elements under which it has been offered or does not comply with the official Mexican standards;

III. If the repaired good is not in adequate condition for its use or destination, within the warranty period, and

IV. In the other cases provided by this law.

In the case of devices, units and goods that due to their characteristics warrant technical knowledge, it will be at the judgment of experts or verification in duly accredited laboratories.

In the case of fraction III, if the consumer chooses to replace the product, it must be new. If, due to the verification, the attorney general's office detects noncompliance with any of the assumptions set forth in this provision, it may order that consumers be informed about the irregularities detected, in accordance with the provisions of article $98 \mathrm{Bis}$, for the effect of that they can demand from the supplier the corresponding bonus.

Article 92 BIS.- Consumers will be entitled to the bonus or compensation when the provision of a service is deficient, is not provided or provided for reasons attributable to the provider, or for other cases provided by law. Article 92 TER.- The bonus referred to in articles 92 and 92 Bis may not be less than twenty percent of the price paid. The payment of said bonus will be made without prejudice to the corresponding compensation for damages.

For the determination of the payment of damages, the judicial authority will consider the payment of the bonus that the supplier would have made in his case.

The corresponding discount in the case of non-compliance referred to in article 92, section I, may be made by the consumer directly to the supplier presenting his receipt or payment receipt of the day in which the violation was detected by the Office of the Attorney General and may not be less to twenty percent of the price paid." 
More abundantly, "The Consumer Magazine has a YouTube channel, where you will find all the programs of the Consumer Magazine TV. In addition to the issues of the Webcast Consumer Magazine; as well as the programs of the Saucy Prophecy Saucer, the Profeco Domestic Technology and the Quality Studies."13. "As can be noted, being published in print and also by technological means, it can be seen in different parts of the Mexican Republic and the world, so that its contents can be taken into account by consumers from other countries, in which the offer of the products of the different suppliers or companies are shown, be they national or transnational as the case may be."

Companies, like people, have their own image that is perceived by those with whom they interact. In this sense, organizations that have a good reputation, enjoy credibility with their clients, an invaluable capital when seeking high productivity rates." 14

From the aforementioned, it should be noted that the repair of damages caused by the supplier, or rather the company, be it manufacturer or merchant, is often not significant the amount delivered to the affected consumer, but if we take Keep in mind that the image and reputation of the merchant or the company can mean greater pressure for the compensation of the affected party, so that in many cases the arrangements or conciliations between consumer and merchant or suppliers are faster, without the need to reach a process before the same Federal Consumer Prosecutor's Office or any court, in some way the companies that usually have an excess of complaints before PROFECO or lawsuits in the courts lose credibility with the public of consumers, since they can disable their positive image that they have acquired over the years with their effort to penetrate markets, both nationally and internationally.
Undoubtedly, companies prefer to reach agreements without having to undergo procedures that may imply higher expenses and social repercussions for the consuming public, which may cause a decrease in sales due to their bad reputation or image, since this is considered an important intangible asset, and having a solid prestige and recognized business status or position in the commercial environment benefits you with your consumers, for the corporate world in which you move and carry out your commercial activity.

Currently, companies should avoid as much as possible the litigation, or lawsuits that are excessively onerous, and that harm their image, and the saying goes well: "A bad settlement is better than a good lawsuit."

Prevention, - according to what the expression says: prevention is better than regret, - is a very useful measure for corporations, so that working correctly with all of the law, and that their businesses are in order, represents an advance for the culture of the entrepreneur, who must keep in mind in his way of working, the terms: win - win $^{15}$ in every exchange of goods and services.

The State as a moral person must seek welfare for the community and above all a social justice; For the development of its activities, it has the support of different moral or physical persons, among which companies, whether public or private, stand out, who contribute to that social prosperity with the satisfaction of needs through the delivery of goods or services that must be of quality for the consuming public that lives in a globalized world with rapid and versatile changes.

\section{Acknowledgments}

I thank the Autonomous University of the State of Mexico of the UAEM Valle de México University Center.

\footnotetext{
13 Retrieved on February 15, 2019, in: https://www.gob.mx/profeco/articulos/revista-delconsumidor?idiom=es

${ }^{14}$ Idem.
}

\footnotetext{
${ }^{15}$ It is a theory of negotiation that was born in the late 70 s and early 80 s was originated and compiled by the Harvard University School of Law. It is a compilation of the best trading practices of various renowned executives. This style of negotiation bases its success on letting both parties give in, so that both win. This theory should focus on the interests of the parties, not on positions or power.
} 


\section{Conclusions}

- The company to fulfil its task carries out administrative, economic, legal activities, among other.

- The company has a social responsibility, facing the national and international context, depending on where its activities are carried out, as well as the impact of its stakeholders.

- All social responsibility of the company must make the company responsible for the damages that it causes to third parties, observing a correct conduct will bring positive things, both in national and foreign companies and vice versa with dishonesty,

- The credibility of the companies constitutes an invaluable intangible capital in the productivity of the same, both in the production of goods and in the provision of services, even many times it has greater value than a tangible one, such as a property.

- The company must seek the well-being of its members, be they partners or employees, the human resource must be treated with dignity, - as well as the community, which is the one to whom its efforts are directed to deliver quality products or services at affordable prices. for the final consumer, whether national or foreign.

- The damages caused by companies must be covered to safeguard the rights of final consumers and in some way, by repairing the damage, the social responsibility of companies is fulfilled, both nationally and internationally.

- The image that companies have with respect to their brands and trade names, have a significant impact on the quick compensation for damages that may be caused to the consuming public, since they take care of their prestige and seek quick compensation so as not to be discredited.
- Globalization has both positive and negative consequences, as the latter may be the case of damages that companies may cause in the provision of goods and services to the community, both internally and externally. When using the term globalize, it involves many aspects, such as cultural, technological, economic, to name a few.

- The company, by carrying out its activities, is no stranger to causing damages to the community that have an important impact on the world of consumers, even more so the effect of globalization gives greater magnitude to said problem, since while its sphere of action is broader, the consequences will be greater since they will impact the international context.

- The company must seek a benefit for its workers, - humane and dignified treatment, complying with the development of quality products, seeking that its environment be benefited by its activities, both for consumers and those who are not, such as interest groups such as settler associations, NGOs, business organizations, residents of the area in which they settle, unions, among others, in some way you have to seek a social benefit rather than a private good.

- When making strategic decisions, the employer must consider the groups or people of interest and not only seek economic gain, but a good for the community, which is their reason for existing and this constitutes a social responsibility.

- Entrepreneur prevention is a very useful measure for corporations, so working correctly with all of the law, and that their businesses are in order, represents an advance for the culture of the company, as well as growth in its image and national and international competitiveness. 
- The company is not only an isolated economic entity that seeks profit, but has an influence on the development of society. It must be remembered that the progress and wealth of a country is measured by the production of goods and services, but these are influenced by different factors in the company, such as culture, co-responsibility of those who work, socially responsible ethics, description transparent reporting both internal and external.

\section{References}

Mantilla Pabón Ana Patricia, Javier Orlando Aguirre Román, Mónica Cristina Puentes Celis. "Responsabilidad social empresarial: la perspectiva de la jurisprudencia constitucional" Criterio Jurídico Santiago de Cali V. 9, No. 2 pág 163 Consultado el 21 de octubre de 2019 en:

https://core.ac.uk/download/pdf/52201928.pdf

Mendizábal Bermúdez. Gabriela (2013) "Análisis de la Responsabilidad empresarial en México de frente a los trabajadores." Instituto de Investigaciones Jurídicas UNAM. México. pág. $126 . \quad$ En. https://revistas.juridicas.unam.mx/index.php/de recho-social/article/downloadd.

Sanromán Aranda. Roberto (2018) "Derecho de las Obligaciones" 4 a Edición Editorial Tirant Lo Blanch. México.

Torres, J. B., \& Alemán, L. S. (2020). La responsabilidad social de la empresa estatal en el ejercicio pleno de los derechos de los trabajadores en la empresa estatal en Cuba REVISTA IUS.Vol.14.Némero45. Cuba.

Vargas Martínez. Elva Esther (2015) "Responsabilidad social empresarial y gestión ambiental el sector hotelero." Editado por UAEM. México.

Legislación consultada.

Código Civil Federal Vigente.

https://www.gob.mx/profeco/articulos/revistadel-consumidor?idiom=es

https://revistadelogistica.com/actualidad/4871/

Ley Federal de Protección al Consumidor. Vigente. 